\author{
Carolina Scagnolari \\ Petra Duda \\ Francesca Bagnato \\ Gabriella De Vito \\ Alessia Alberelli \\ Vito Lavolpe \\ Enrico Girardi \\ Valentina Durastanti \\ Maria Trojano \\ Ludwig Kappos \\ Guido Antonelli
}

\section{Pharmacodynamics of interferon beta in multiple sclerosis patients with or without serum neutralizing antibodies}

Received: 28 March 2006

Received in revised form: 14 June 2006

Accepted: 22 June 2006

Published online: 10 April 2007

C. Scagnolari · G. De Vito · A. Alberelli

G. Antonelli

Dept. of Experimental Medicine -

Virology Section

"La Sapienza" University

Rome, Italy

P. Duda, MD · L. Kappos, MD ( $\square)$

Dept. of Neurology and Research

University Hospital

Basel, Switzerland

Tel.: +41-61-2654464

Fax: +41-61-2655344

E-mail: lkappos@uhbs.ch

F. Bagnato $\cdot$ V. Durastanti

Neuroimmunology Branch, NINDS, NIH

Bethesda, USA

V. Lavolpe $\cdot$ M. Trojano

Dept. of Neurological and Psychiatric

Sciences

University of Bari

Bari, Italy

E. Girardi

National Institute for Infectious Diseases

"L. Spallanzani"

Rome, Italy
Abstract To analyze the in vivo biological effect of anti-interferon beta (IFN-beta) neutralizing antibodies (NABs), blood concentrations of neopterin, beta2microglobulin (Beta2-MG), mRNA-dependent myxovirusresistant protein $\mathrm{A}(\mathrm{MxA})$ and dsRNA-dependent protein kinase (PKR) were measured before (predose) and 24 hours after (postdose) IFN-beta administration in 49 patients with multiple sclerosis (MS) with $(\mathrm{n}=25)$ and without $(\mathrm{n}=24)$ NABs.

The results indicated that predose levels of MxA-mRNA and PKR-mRNA were highly variable [coefficient of variation (CV) > $100 \%$ ] among patients. A lower inter-individual variability was observed for pre-dose levels of Beta2-MG and neopterin (CVs of $29 \%$ and $44 \%$, respectively).

Significantly lower pre- and post-dose blood levels of IFN induced markers, except for postdose PKR-mRNA ( $p=0.09)$, were seen in $\mathrm{NAB}+$ compared with $\mathrm{NAB}-$ patients and between patients with high $\left(>200 t_{1 / 10}\right)$ and low $\left(\leq 200 t_{1 / 10}\right)$ NAB titers. A significant inverse correlation between NAB titer and pre-dose levels of the above IFN-induced markers was found. In summary, our findings confirm that NABs affect absolute concentrations of IFN-beta induced markers and suggest that such an effect occurs in a titer-dependent manner.

Key words interferon beta . neutralizing antibodies . multiple sclerosis .

MxA - PKR - Beta2-microglobulin $\cdot$ neopterin

\section{Introduction}

Interferon beta (IFN-beta) is a first-choice therapeutic strategy for patients with relapsing-remitting (RR) multiple sclerosis (MS) [1] and those with secondary progressive (SP) MS experiencing continuing relapse activity [2, 3]. Neutralizing antibodies
(NABs) against IFN-beta may occur in variable percentages of patients [2, 4-8]. The clinical significance of NABs has been a matter of controversy and has been extensively investigated ever since the initial descriptions in MS patients [9-23]. Monitoring blood levels for IFN-beta-induced compounds and expression of IFN type I-inducible genes provides an 
Table 1 Demographics and clinics of patients (NABs, neutralizing antibodies; MS, multiple sclerosis; RR, relapsing-remitting; SP, secondary progressive; EDSS, expanded disability status scale)

\begin{tabular}{lll}
\hline & Patients without NABs $(\mathbf{n}=\mathbf{2 4})$ & Patients with NABs $(\mathbf{n}=\mathbf{2 5})$ \\
\hline Age (years)* & $41.0 \pm 11.3$ & $45.2 \pm 12.9$ \\
Gender (females/males) & $19 / 5$ & $19 / 6$ \\
MS duration (years) & $13.8 \pm 8.7$ & $10.7 \pm 3.8$ \\
Disease course & RR (10); SP (14) & RR (9); SP (16) \\
EDSS* & $5.3 \pm 1.6$ & $4.5 \pm 1.6$ \\
\hline
\end{tabular}

* mean \pm SD

interesting approach to studying the in vivo biological effects of NABs.

Serum concentrations of IFN-induced compounds have been examined already to some extent, in patients with RRMS undergoing IFN-beta therapy. Decreases in serum levels of neopterin, beta2-microglobulin (Beta2-MG) and in peripheral blood mononuclear cell (PBMC) concentrations of mixovirus-resistant protein $\mathrm{A}(\mathrm{MxA})$-mRNA were found in RRMS patients who developed NABs [24-31]. However, the findings were contradictory [28]. Further questions still remain as to whether lack of efficacy of IFN-beta in NAB+ patients is related to these antibodies in a titer-dependent manner. Indeed, while some studies described an association between NAB titer and loss of IFN-beta biological response[24, 27-29, 31], others failed to demonstrate such an association $[25,30]$.

In order to gain new insights into these issues, the pharmacodynamic profile of IFN-beta in patients with MS, both with and without NABs, was first defined by measuring neopterin, Beta2-MG and MxA-mRNA concentrations in blood immediately before and 24 hours after IFN-beta injection. In addition, preand post-dose intracellular levels of the IFN-induced dsRNA-dependent protein kinase (PKR)-mRNA were also determined.

The changes in PBMC PKR-mRNA have been so far only marginally studied in patients with MS [32].

To address the role of NAB titers in affecting the pharmacodynamics of IFN-beta patients with NABs were finally classified in two different groups based on NAB titers.

\section{Materials and methods}

\section{Patients and study design}

49 patients with clinically definite MS according to Poser criteria [33], who were undergoing therapy with recombinant (r) IFN-betalb (Betaferon ${ }^{\circledR}$, Schering, Berlin, Germany) given at $8 \times 10^{6}$ IU subcutaneously (SC) every other day were included consecutively in this cross-sectional study. All patients were required to sign an informed consent form prior to inclusion. Local Ethics Committees and/or Institutional Review Boards approved the study.
In Table 1 the demographics and clinics of patients at the time of sample collection are summarized. Patients with NABs had been undergoing therapy for $2.8 \pm 1.9$ years, while NAB- patients had been taking IFN-beta for $4.1 \pm 1.7$ years $(p=0.08)$.

Samples for each individual were collected according to the following scheme: (i) pre-dose, that is immediately before an rIFNbetalb injection, corresponding to 48 hours (up to 72 hours in a few cases) after the previous rIFN-betalb injection; (ii) post-dose, that is 24 hours after an rIFN-betalb injection (18 hours in a very few cases). Pre-dose samples served for NAB measurements, whereas pre- and post-dose samples were collected for measurement of blood concentrations of Beta2-MG, neopterin, MxA and PKR.

The timing of sample collection was based upon both ethical and biological considerations representing a trade-off between feasibility and optimal data acquisition. First, only two sample collections (i.e. pre- and post-dose) were considered to be acceptable by a local ethics committee. Second, previous studies showed that changes in type I-IFN-induced compounds (i.e. Beta2-MG, neopterin and MxA protein) are still sustained 24 hours after IFNbeta injection in patients with RRMS [26, 28, 31, 34].

In the light of the above-mentioned considerations, samples were collected at 24-hours post-dose in the present study.

\section{Biological evaluations}

Venous peripheral blood from each patient was drawn into tubes containing ethylenediaminetetraacetic acid and into anticoagulantfree tubes. PBMCs were separated using Ficoll-Hypaque gradient sedimentation; $5 \times 10^{6}$ PBMCs were collected, pelleted and frozen at $-80^{\circ} \mathrm{C}$ until required. Serum samples, obtained after centrifugation, were stored at $-80^{\circ} \mathrm{C}$ until used.

\section{Detection of IFN-beta NAB}

Antibody titers were determined by neutralization against $10 \mathrm{IU}$ of rIFN-betalb as previously described [6]. Sera were routinely inactivated at $56^{\circ} \mathrm{C}$ for 30 minutes before titration. Then $60 \mu$ l of twofold serial dilutions (starting from 1:10) of sample or control sera were incubated at $37^{\circ} \mathrm{C}$ with $60 \mu \mathrm{l}$ containing $20 \mathrm{IU} / \mathrm{ml}$ of rIFN-beta. After 1 hour, $100 \mu \mathrm{l}$ of individual mixtures were added to duplicate monolayers of human lung carcinoma (A549) cells in 96-well microtiter plates. After 18-24 hours of culture and extensive washing, the cells were challenged with the encephalomyocarditis virus and incubated at $37^{\circ} \mathrm{C}$ for 24 hours. Controls included a titration of the IFN preparations used in the respective assays and of a reference standard antibody to IFN-beta (National Institutes of Health, Bethesda, MD; code GO38-501-572). Any antiviral activity and its neutralization were assessed on the basis of the virus-induced cytophatic effect (CPE), and to quantify this, the cells were stained with crystal violet in $20 \%$ ethanol. The dye taken up by the cells was eluted with $33 \%$ acetic acid and its absorbance measured in a microdensitometer at $540 \mathrm{~nm}\left(\mathrm{OD}_{540}\right)$. The extent of virus-induced 
CPE, its inhibition by IFN-beta, and the reversal of this by NABs were shown by the amount of dye eluted from each well. Titers were calculated using Kawade's method and expressed logarithmically as $t_{1 / 10}$, namely the dilution of serum reducing 10 laboratory units (LU) per $\mathrm{ml}$ of IFN to $1 \mathrm{LU} / \mathrm{ml}[35]$.

Serum samples were routinely assayed for, and all were found to be free from, endogenous or residual IFN activity.

The neutralizing activity of the titred sera $\left(\geq 80 \mathrm{t}_{1 / 10}\right.$ that corresponds to $(\geq 1.9 \mathrm{Log})$ was characterized as being due specifically to the presence of IFN antibodies as previously described [36]

Patients were assigned to one of three groups according to their NAB status: NAB-negative (NAB-), NAB low positive $\left(\leq 200 t_{1 / 10}\right.$ which corresponds to $\leq 2.3 \mathrm{Log}$; $\mathrm{LP}-\mathrm{NAB}+$ ) and $\mathrm{NAB}$ high positive ( $>200 \mathrm{t}_{1 / 10}$, which corresponded to $>2.3 \mathrm{Log}$; $\mathrm{HP}-\mathrm{NAB}+$ ).

\section{Detection of neopterin and Beta2-MG}

Serum concentration of neopterin (DRG Instruments $\mathrm{GmbH}$, Marburg, Germany) and Beta2-MG (S.P.A. Italiana Laboratori Bouty, Milan, Italy) were immunoassayed following the manufacturer's instructions using sera stored at $-80 \mathrm{C}^{\circ}$ until tested. Serum samples were tested in duplicate.

\section{Taqman quantitative RT-PCR for MxA- and PKR-mRNA}

MxA and PKR genes transcripts in PBMCs from MS patients were quantified by a real time $5^{\prime}$ exonuclease reverse transcript-polymerase chain reaction (RT-PCR Taqman) assay using the ABI 7700 sequence detector (Applied Biosystems, Monza, Italy). Briefly, total cell RNA and DNA were concomitantly extracted from $5 \times 10^{6}$ PBMCs using Trizol reagent (Gibco BRL, NY, USA) following the manufacturer's instructions. The RNA was dissolved in $50 \mu \mathrm{l}$ of RNAse-free water and the quantitation of MxA- or PKR-mRNA was performed in a Taqman assay after generation of cDNA. The following primers and probe for MxA (forward primer, $5^{\prime}$-CTGCC TGGCAGAAAACTTACC- $3^{\prime}$ reverse primer, $5^{\prime}$-CTCTGTTATTCTC TGGTGAGTCTCCTT- $3^{\prime}$ probe, 5'CATCACACATATCTGTAAA TCTCTGCCCCTGTTAGA-3') or for PKR (forward primer, $5^{\prime}$ TGCTACTACGTGTGAGTCCCAAA-3' reverse primer, $5^{\prime}$ - TGATG TATCTGCTGAGAAGTCACCT- $3^{\prime}$ probe, 5'-CAACTCTTTAGTGA CCAGCACACTCGCTTCT- $3^{\prime}$ ) were added to the universal PCR master mix (Applied Biosystems, Foster City, CA, USA) at 300 and $100 \mathrm{nM}$, respectively, in a final volume of $50 \mu \mathrm{l}$. The standards were obtained by cloning the $525 \mathrm{bp} \mathrm{MxA}$ fragment or $394 \mathrm{bp}$ PKR fragment into the pCRII plasmid using a TOPO TA cloning kit (In Vitrogen Corporation, San Diego, CA, USA). The DNA from the cloned plasmids was subsequently transcribed using SP6/T7 RNA polymerase under the conditions recommended by the supplier (Promega Corporation, Madison, WI, USA). A linear distribution $(\mathrm{r}=0.99)$ was obtained between $10^{1}$ and $10^{8}$ copies of MxA- or PKR-RNA.

PBMC-MxA and PKR transcripts were normalized to DNA values and expressed as the number of copies of MxA- or PKRmRNAs/ng DNA. DNA levels were measured by using a spectrophotometer at $260 \mathrm{~nm}$.

\section{Statistical analysis}

Descriptive statistics were provided for the entire population to report patient demographics/clinics and blood concentrations of neopterin, Beta2-MG, and MxA- and PKR-mRNA.

The coefficient of variation $(\mathrm{CV})$ was used to measure interpatient variability in blood concentrations of biological products. The CV is the ratio of the standard deviation (SD) of the mean of each variable to the mean, expressed as a percentage $[\mathrm{CV}=(100)$
(SD/mean)]. Relative increases in levels of neopterin, Beta2-MG, and MxA-and PKR-mRNA from pre- to post-dose were given as the post- to pre-dose levels ratio. Absolute increases above baseline were given by the differences between post- and pre-dose values. Differences between patient groups in terms of blood concentrations and relative or absolute increases in surrogate biological markers for IFN action were analyzed using the Kruskal-Wallis test. Follow-up Mann-Witney U tests were undertaken when differences were found. Pearson's $r$ coefficient was calculated to assess the correlation between levels of Beta2-MG, neopterin, and Log MxA/PKR-mRNA with Log NAB titers.

Statistical analysis was performed by SPSS v.11 for Windows ${ }^{\circledR}$. A p-value of $\leq 0.05$ was considered significant throughout the statistical analyses.

\section{Results}

\section{Inter-patient variability in pre- and post-dose lev- els of neopterin, Beta2-MG, and MxA- and PKR-mRNAs}

Individual levels of neopterin, Beta2-MG, and MxAand PKR-mRNAs at pre- and post-dose are shown in Figure 1. Pre-dose CVs were $44 \%$, 29\% for neopterin and Beta2-MG, and $>100 \%$ for MxA- and PKR-mRNAs; post-dose CVs were $45 \%, 28 \%$ for neopterin and Beta2MG and $>100 \%$ for MxA- and PKR-mRNAs. This finding demonstrates a marked interpatient variability in the steady-state and IFN-induced levels of markers in patients with MS undergoing IFN-beta treatment.

\section{Influence of NAB on the expression of IFN-induced markers}

Absolute pre- and post-dose levels of each IFN induced marker in $\mathrm{NAB}+$ and $\mathrm{NAB}$ - patients, expressed as mean $( \pm$ SD) and median, are shown in Table 2. NAB+ patients had significantly lower concentrations of each marker at each time point except for Beta2-MG blood post-dose concentrations $(\mathrm{p}=0.09)$. When patients were grouped together as NAB-, LP-NAB+ and HP-NAB+ (see Table 2), the highest $(p<0.02)$ mean values of neopterin, Beta2-MG, and MxA- and PKRmRNAs were observed in NAB- patients compared with either LP-NAB+ or HP-NAB+ patients. The exceptions were the values of PKR-mRNA at post-dose, which were found to be lower, although not significantly $(p=0.09)$ in HP-NAB+ patients versus $\mathrm{LP}-\mathrm{NAB}+$ patients. The lowest values were found in HP$\mathrm{NAB}+$ patients compared with each remaining group.

Significant inverse correlations between the Log titer of NABs and the pre-dose expression of neopterin $(\mathrm{r}=-0.54 ; \mathrm{p}<0.05)$, Beta2-MG $(\mathrm{r}=-0.34$; $\mathrm{p}<0.05), \log$ MxA-mRNA $(\mathrm{r}=-0.49 ; \mathrm{p}<0.05)$, and Log PKR-mRNA $(r=-0.35 ; p<0.05)$ were recorded.

Upon examining IFN beta-induced modifications of the values of each compound, it was found that no 
Fig. 1 Change of neopterin (panel A), Beta2-MG (panel B), Log MxAmRNA (panel C) and Log PKR-mRNA (panel D) expression levels after rIFN-beta1b injection in the entire patients group. (Beta2-MG, beta2microglobulin; MxA, mixovirusresistant protein $A ;$ PKR, dsRNAdependent protein kinase; rIFN, recombinant interferon)
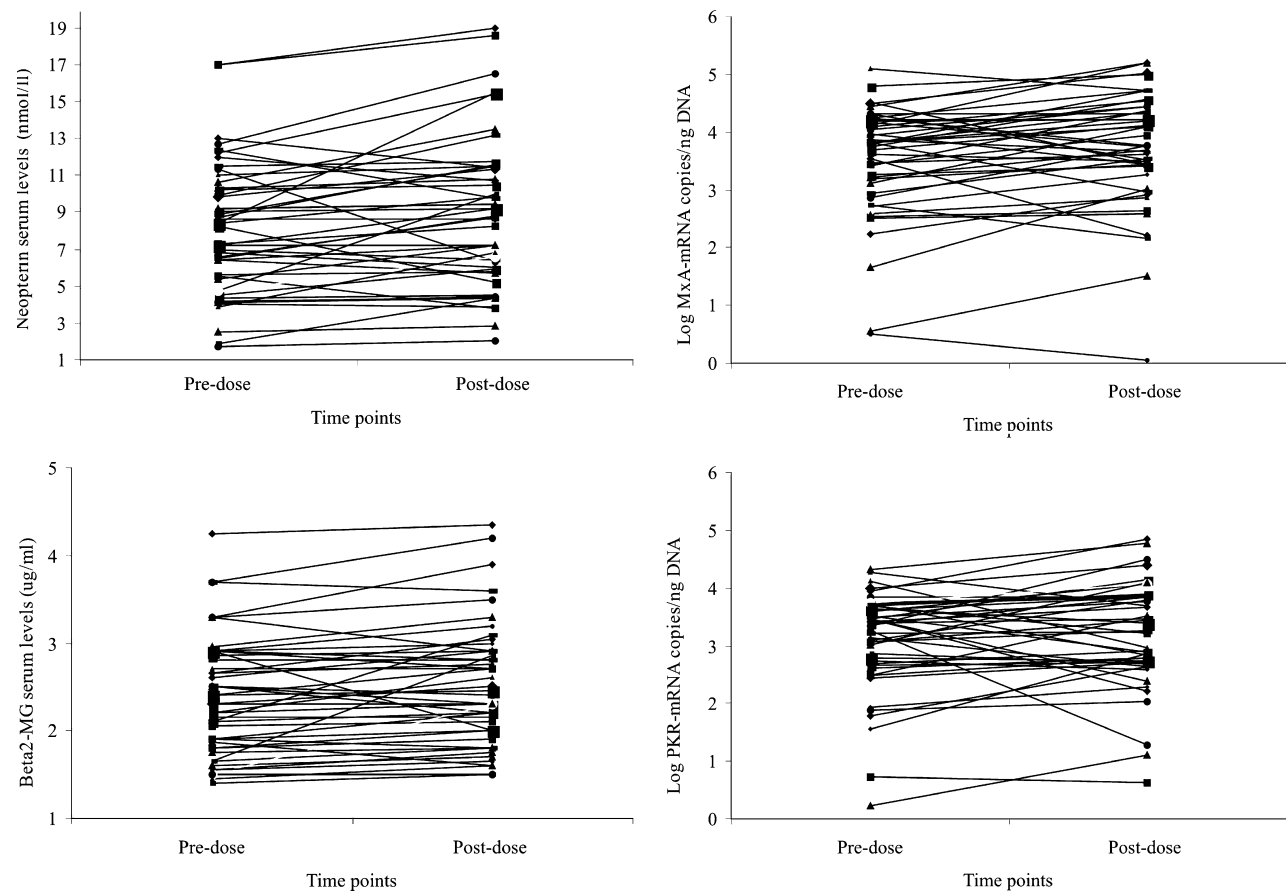

Table 2 Influence of NABs on expression of interferon-induced markers (NABs, neutralizing antibodies; LP, low positive; HP, high positive; Beta2-MG, beta2-microglobulin; MxA, myxovirus-resistant protein $A$; PKR, dsRNA-dependent protein kinase)

\begin{tabular}{llllll}
\hline & & NAB- $(\mathbf{n}=\mathbf{2 4})$ & All NAB+ $(\mathbf{n}=\mathbf{2 5})$ & LP-NAB+ $(\mathbf{n}=\mathbf{1 3})$ & HP-NAB+ $(\mathbf{n}=\mathbf{1 2})$ \\
\hline Neopterin $(\mathrm{nmol} / \mathrm{l})$ & Pre-dose & $9.6 \pm 3.3(9.5)$ & $6.2 \pm 2.8(5.6)$ & $7.6 \pm 2.8(7.3)$ & $4.7 \pm 2.4(4.2)$ \\
& Post-dose & $10.7 \pm 4.1(10.8)$ & $6.9 \pm 2.7(6.8)$ & $8.2 \pm 2.4(8.6)$ & $5.5 \pm 2.7(4.5)$ \\
Beta2-MG $(\mu \mathrm{g} / \mathrm{ml})$ & Pre-dose & $2.5 \pm 0.6(2.5)$ & $2.1 \pm 0.5(1.9)$ & $2.3 \pm 0.7(2.4)$ & $1.9 \pm 0.5(1.9)$ \\
& Post-dose & $2.6 \pm 0.7(2.6)$ & $2.2 \pm 0.5(2.2)$ & $2.6 \pm 0.6(2.5)$ & $2.0 \pm 0.5(1.9)$ \\
MxA-mRNA (copies/ng DNA) & Pre-dose & $20433.7 \pm 27671.3(11980.6)$ & $6016.5 \pm 11076.9(1744.5)$ & $6712.2 \pm 6831.9(4789.1)$ & $1340.4 \pm 1442.0(636.3)$ \\
& Post-dose & $37486.4 \pm 48604.3(16498.6)$ & $9699.4 \pm 14488.1(2955.1)$ & $15217.3 \pm 17184.1(5998.6)$ & $1815.1 \pm 1879.8(914.9)$ \\
PKR-mRNA (copies/ng DNA) & Pre-dose & $5629.0 \pm 5832.3(4224.7)$ & $2077.3 \pm 2481.5(1190.5)$ & $1978.9 \pm 1761.0(1385.6)$ & $1415.0 \pm 1543.8(1095.6)$ \\
& Post-dose & $11600.3 \pm 19439.9(4985.0)$ & $3324.7 \pm 4414.9(778.1)$ & $3777.8 \pm 5003.0(1729.0)$ & $2620.1 \pm 3951.2(587.3)$ \\
\hline
\end{tabular}

Values are expressed in mean \pm SD (median)

differences in increases relative to baseline were present in NAB-, LP-NAB+ and HP-NAB+ patients (Figure 2). The latter suggests that NAB probably do not abolish completely the capability of IFN beta to exert its biological activity.

\section{Discussion}

Several approaches have been used to establish whether the development of NABs affects the pharmacodynamics of IFN-beta in patients with MS. Our results confirm that IFN-beta NABs reduce pre- and post-dose blood concentrations of several IFN-induced markers. There were, however, some further findings, which we consider, deserve some attention.
The present study indicates, for the first time to our knowledge that the measurement of PKR-mRNA is worth taking into account when studying the pharmacodynamic profile of IFN-beta in MS patients. Questions remain as to whether PKR protein measurements provide a clinically useful marker for monitoring and predicting the effectiveness of IFNbeta in MS patients, as this study was not powered and designed for this purpose.

High inter-patient variability was observed in neopterin and Beta2-MG pre- and post-dose serum levels, as well as in PBMC MxA and PKR pre- and post-dose transcripts. This finding is not new and is most likely due to heterogeneity in the immunology of patients with MS. Indeed, Chieux and co-authors [37] reported that, in contrast to moderate differences in MxA expression in healthy individuals, clinically 

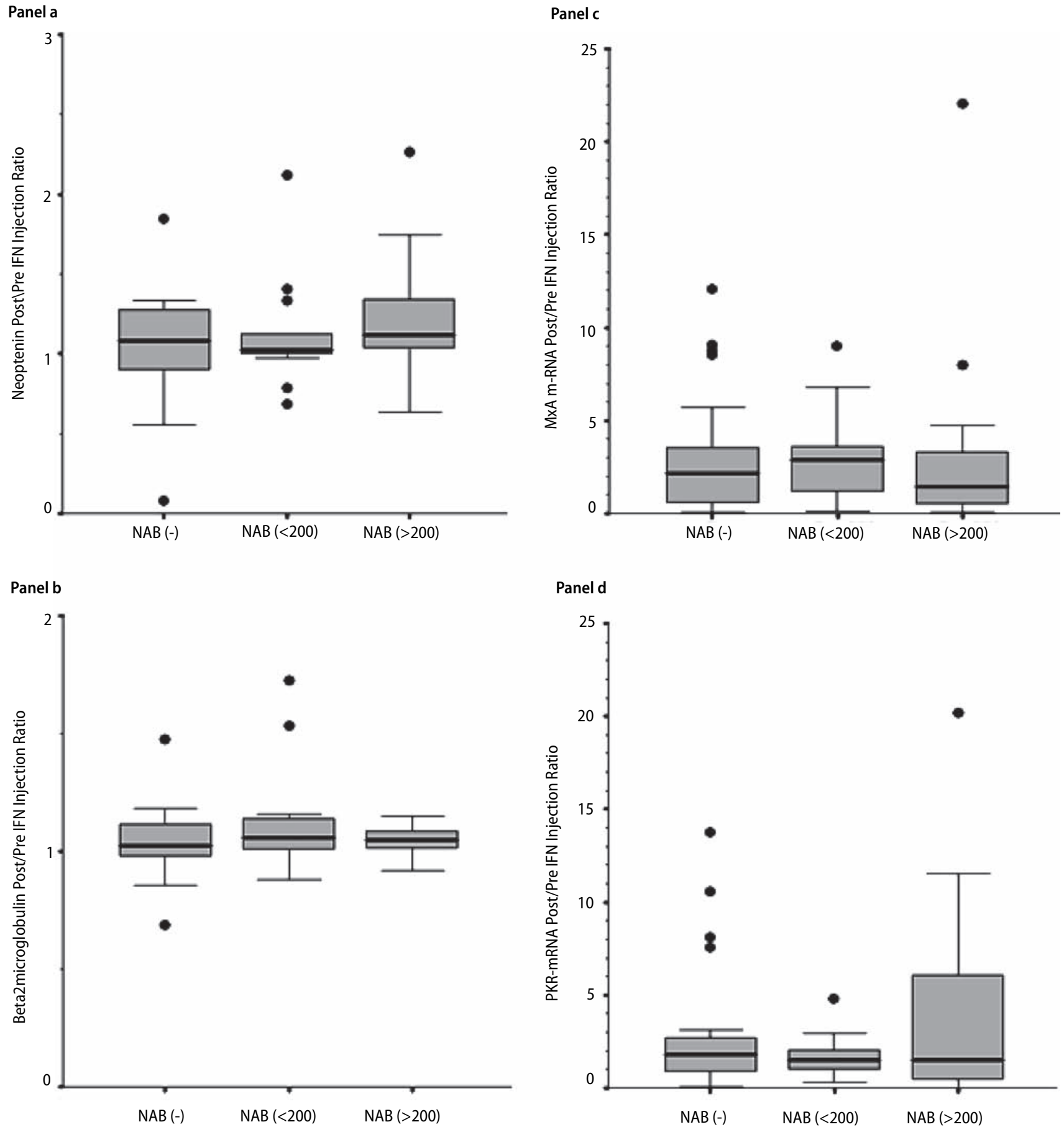

Fig. 2 Post/pre-dose ratios of neopterin (panel A) and Beta2-MG (panel B), peripheral blood mononuclear cells MxA-mRNA (panel C), PKR-mRNA (panel D) in NAB$\left(<10 \mathrm{t}_{1 / 10}\right), \mathrm{LP}-\mathrm{NAB}+\left(\left(200 \mathrm{t}_{1 / 10}\right)\right.$ and HP-NAB+ $\left(\leq 200 \mathrm{t}_{1 / 10}\right)$ patients. (Beta2-MG, beta2-microglobulin; MxA, myxovirus-resistant protein A; PKR, dsRNA-dependent protein kinase; NAB, neutralizing antibody; LP, low positive; HP, high positive) Box and whiskers plots are used to present data. In these graphs, boxes represent interquartile ranges; horizontal bars stand for median value; vertical bars extend to the smallest and the largest observations within 1, 5 interquartile range from the extremes of the box. Outliers are displayed as individual points

stable patients with RRMS have high inter-individual variance in MxA expression. This observation has been extended here and our results support the idea that each MS patient might possess a specific and individual capacity to respond to IFN-beta. Several factors could contribute to this wide range of vari- 
ability, including the immunological (e.g. change in Th1/Th2 ratio or cross-talk from other cytokineactivated pathways) and genetic characteristics of patients [38-41].

Apart from these speculations, the reasons for the high level of inter-individual variability remain unclear at present.

While differences were found between patients with and without NABs, in pre and post-dose concentrations of neopterin and Beta2-MG as well as MxA and PKR specific transcripts (Table 2), and in absolute increases over the baseline of the same markers (data not shown), no differences were seen in the relative post-injection increase in any of the examined compounds (Figure 2). The latter has not been previously investigated and was an intriguing finding. Several considerations can be formulated in order to explain our finding. First one could speculate that as soon as IFN-beta is administered it reaches its target cells being free to exert its action. Later on, when the molecule reaches the bloodstream, it can be exposed to the neutralization effect of circulating NABs.

Second, little is known about the reaction of antiIFN antibody neutralization in terms of molar concentrations. The latter would deserve further investigations in order to understand the neutralization capability of NABs. At present, we may only speculate that following IFN-beta injection, NABs do not neutralize all IFN molecules and those left can still bind to the receptor, thus allowing some effector expression. Third, binding between IFN and NAB is reversible and anti-IFN-beta NABs with different affinity and specificity have been demonstrated in vivo [42-45].

It is tempting to speculate that the above factors may influence the efficiency of the NAB neutralization reaction. Recently we obtained evidence that the degree of IFN-beta-induced expression of markers may strictly depend on their pre-dose levels (Scagnolari C, et al., unpublished). This suggests that the ratio post/ pre-dose, rather than the absolute increases, may be more representative of the effector mechanism elicited by IFN-beta treatment.

Whatever the explanation is, further studies are warranted in order to better understand these preliminary findings. A more extensive pharmacodynamic profile would possibly provide further insights. It seems also possible that at least in some instances the level of induction of IFN- beta-induced markers decreases during IFN-beta treatment due to a "tachyphylaxis-like" phenomenon [28]. These considerations have to be taken into account to fully understand the capability of NAB to neutralize the activity of IFN-beta.
A third possible source of variability, may derive from circadian variations because in this study, drug injection and sample collection after 24 hours did not always occur at the same time of the day.

Even considering all these limitations, our data provide new insights in the capability of NABs to completely impede IFN action in vivo.

Our data also indicate a correlation between NAB titers and the expression of IFN-action markers. More specifically, we observed that HP-NAB+ patients (e.g. $>200 \mathrm{t}_{1 / 10}$ ) were associated with a marked inhibition of the in vivo biological response compared with NAB- or LP-NAB+ patients. This is in accordance with previous studies, which showed a significant decrease in Beta2-MG, neopterin and MxA protein in patients with persistently high levels of NABs [24, 27-29,31] but contradicts others who found that IFN-beta bioavailability was completely abolished, irrespective of NAB titers [25].

This discrepancy can be explained by considering that other factors beside NABs could affect IFN-beta bioactivity in patients with MS. These include abnormal IFN signalling [46], decreased expression of the IFN type I receptor on the cell surface [47], release of free IFN-alpha/beta type I receptors into the circulation $[48,49]$ and the presence of IFN type I inhibitory proteins $[48,50]$. Recently it has been shown that two members of the suppressor of cytokine signalling (SOCS) protein family, SOCS-1 and SOCS-3, also inhibit IFN-induced expression of the antiviral proteins $2^{\prime} 5^{\prime}$-OAS and MxA [51].

In conclusion our data demonstrate that the development of NABs in patients with MS during therapy leads to a decrease in absolute pre- and post-dose levels and changes in surrogate markers for IFN. However, the data also indicate that surrogate markers for IFN increase significantly on IFN-beta administration, even in the presence of NABs. Hence, serum NABs seem to be unable to abolish entirely the effects of IFN-beta administration. Whether this effect of NABs is fully NAB titer-dependent is still debatable and warrants further investigation in larger cohorts of patients and at shorter intervals.

The main aim of this study was to address in detail the pharmacodynamics of IFN-beta in the presence of serum circulating $\mathrm{NAB}$, and not to address the general issue of NAB impact from a clinical point of view. In order to reach definite conclusions on this issue, further studies combining clinical and biological investigations in the same individuals are certainly warranted.

- Acknowledgements This work was supported in part by a grant to G. A. from FISM-Fondazione Italiana sclerosi multiplacod 2004/R/1. L. K. and P.D. 's work was supported by the Swiss MS Society. 


\section{References}

1. Markowitz C (2004) Development of interferon-beta as a therapy for multiple sclerosis. Expert Opin Emerg Drugs 9:363-374

2. Cohen JA, Cutter GR, Fischer JS, Goodman AD, Heidenreich FR, Kooijmans MF, Sandrock AW, Rudick RA, Simon JH, Simonian NA, Tsao EC, Whitaker JN; IMPACT Investigators (2002) Benefit of interferon beta-1a on MSFC progression in secondary progressive MS. Neurology 59:679-687

3. Kappos L, Weinshenker B, Pozzilli C, Thompson AJ, Dahlke F, Beckmann K, Polman C, McFarland H, European (EU-SPMS) Interferon beta-1b in Secondary Progressive Multiple Sclerosis Trial Steering Committee, Independent Advisory Board; North American (NASPMS) Interferon beta-1b in Secondary Progressive Multiple Sclerosis Trial Steering Committee and Independent Advisory Board (2004) Interferon beta$1 \mathrm{~b}$ in secondary progressive MS: a combined analysis of the two trials. Neurology 63:1779-1787

4. Kivisakk P, Alm GV, Fredrikson S, Link $\mathrm{H}$ (2000) Neutralizing and binding anti-interferon-beta (IFN-beta) antibodies A comparison between IFNbeta-1a and IFN-beta-1b treatment in multiple sclerosis. Eur J Neurol 7:27-34

5. Perini P, Facchinetti A, Bulian P, Massaro AR, Pascalis DD, Bertolotto A, Biasi G, Gallo P (2001) Interferon-beta (INF-beta) antibodies in interferonbetala- and interferon-betalb-treated multiple sclerosis patients. Prevalence, kinetics, cross-reactivity, and factors enhancing interferon-beta immunogenicity in vivo. Eur Cytokine Netw 12:56-61

6. Scagnolari C, Bellomi F, Turriziani O, Bagnato F, Tomassini V, La Volpe V, Ruggeri M, Bruschi F, Meucci G, Dicuonzo G, Antonelli G (2002) Neutralizing and binding antibodies to IFN-beta: relative frequency in relapsing-remitting multiple sclerosis patients treated with different IFN-beta preparations. J Interferon Cytokine Res 22:207-213

7. Bertolotto A, Malucchi S, Sala A, Orefice G, Carrieri PB, Capobianco M, Milano E, Melis F, Giordana MT (2002) Differential effects of three interferon betas on neutralising antibodies in patients with multiple sclerosis: a follow up study in an independent laboratory. J Neurol Neurosurg Psychiatry 73:148153
8. Polman C, Kappos L, White R, Dahlke F, Beckmann K, Pozzilli C, Thompson A, Petkau J, Miller D; European Study Group in Interferon Beta-1b in Secondary Progressive MS (2003) Neutralizing antibodies during treatment of secondary progressive MS with interferon beta-1b. Neurology 60:37-43

9. The IFNB Multiple Sclerosis Study Group and the University of British Columbia MS/MRI Analysis Group (1996) Neutralizing antibodies during treatment of multiple sclerosis with interferon beta-1b: experience during the first three years. Neurology 47:889894

10. PRISMS Study Group and the University of British Columbia MS/MRI Analysis Group (2001) PRISMS-4: Long-term efficacy of interferon-beta1a in relapsing MS. Neurology 56:16281636

11. Panitch H, Goodin DS, Francis G, Chang P, Coyle PK, O'Connor P, Monaghan E, Li D, Weinshenker B; EVIDENCE Study Group. Evidence of Interferon Dose-Response: European North American Comparative Efficacy; University of British Columbia MS/ MRI Research Group (2002) Randomized, comparative study of interferon b-1a treatment regimen in MS: The EVIDENCE Trial. Neurology 59:14961506

12. Li DK, Zhao GJ, Paty DW; University of British Columbia MS/MRI Analysis Research Group (2001) The SPECTRIMS Study Group. Randomized controlled trial of interferon-beta-1a in secondary progressive MS: MRI results. Neurology 56:1505-1513

13. Sorensen PS, Ross C, Clemmesen KM, Bendtzen K, Frederiksen JL, Jensen K, Kristensen O, Petersen T, Rasmussen S, Ravnborg M, Stenager E, Koch-Henriksen N; Danish Multiple Sclerosis Study Group (2003) Clinical importance of neutralising antibodies against interferon beta in patients with relapsing-remitting multiple sclerosis. Lancet 362:1184-1191

14. Malucchi S, Sala A, Gilli F, Bottero R, Di Sapio A, Capobianco M, Bertolotto A (2004) Neutralizing antibodies reduce the efficacy of beta IFN during treatment of multiple sclerosis. Neurology 62:2031-2037

15. Frank JA, Richert N, Bash C, Stone L, Calabresi PA, Lewis B, Stone R, Howard T, McFarland HF (2004) Interferonbeta-1b slows progression of atrophy in RRMS: Three-year follow-up in NAband NAb+ patients. Neurology 62:719725
16. Giovannoni G, Goodman A (2005) Neutralizing anti-IFN-beta antibodies. How much more evidence do we need to use them in practice? Neurology 65:6-8

17. Kappos L, Clanet M, Sandberg-Wollheim MS, Radue EW, Hartung HP, Hohlfeld R, Xu J, Bennett D, Sandrock A, Goelz S (2005) Neutralizing antibodies and efficacy of interferon beta-1a. A 4year controlled study. Neurology 65:4047

18. Jacobs LD, Beck RW, Simon JH, Kinkel RP, Brownscheidle CM, Murray TJ Simonian NA, Slasor PJ, Sandrock AW (2000) Intramuscular interferon beta1a therapy initiated during a first demyelinating event in multiple sclerosis. CHAMPS Study Group. N Engl J Med 343:898-904

19. Jacobs LD, Cookfair DL, Rudick RA, Herndon RM, Richert JR, Salazar AM, Fischer JS, Goodkin DE, Granger CV, Simon JH, Alam JJ, Bartoszak DM, Bourdette DN, Braiman J, Brownscheidle CM, Coats ME, Cohan SL, Dougherty DS, Kinkel RP, Mass MK, Munschauer FE 3rd, Priore RL, Pullicino PM, Scherokman BJ, Whitham $\mathrm{RH}$, et al. (1996) Intramuscular interferon beta la for disease progression in relapsing-remitting multiple sclerosis. Ann Neurol 39:285-294

20. Durelli L, Verdun E, Barbero P, Bergui M, Versino E, Ghezzi A, Montanari E, Zaffaroni M; Independent Comparison of Interferon (INCOMIN) Trial Study Group (2002) Every-other-day interferon beta-1b versus once-weekly interferon beta-1a for multiple sclerosis: results of a 2-year prospective randomised multicentre study (INCOMIN). Lancet 359:1453-1460

21. Knobler RL, Greenstein JI, Johnson KP, Lublin FD, Panitch HS, Conway K, Grant-Gorsen SV, Muldoon J, Marcus SG, Wallenberg JC, et al (1993) Systemic recombinant human interferonbeta treatment of relapsing-remitting multiple sclerosis: pilot study analysis and six-year follow-up. J Interferon Cytokine Res 13:333-340

22. Antonelli G, Bagnato F, Pozzilli C, Simeoni E, Bastianelli S, Currenti M, De Pisa F, Fieschi C, Gasperini C, Salvetti M, Dianzani F (1998) Development of neutralizing antibodies in patients with multiple sclerosis treated with IFN- $\beta 1$ a. J Interferon Cytokine Res 18:345-350 
23. PRISMS (PREVENTION OF RELAPSES AND DISABILITY BY INTERFON BETA-1A SUBCUTANEOUSLY IN MULTIPLE SCLEROSIS) STUDY GROUP (1998) Randomized doubleblind placebo-controlled study of interferon beta-1a in relapsing/remitting multiple sclerosis. Lancet 352:1498-1504

24. Rudick RA, Simonian NA, Alam JA, Campion M, Scaramucci JO, Jones W, Coats ME, Goodkin DE, WeinstockGuttman B, Herndon RM, Mass MK, Richert JR, Salazar AM, Munschauer FE, Cookfair DL, Simon JH, Jacobs LD (1998) Incidence and significance of neutralizing antibodies to interferon beta-1a in multiple sclerosis. Multiple Sclerosis Collaborative Research Group (MSCRG). Neurology 50:1266-1272

25. Deisenhammer F, Reindl M, Harvey J, Gasse T, Dilitz E, Berger T (1999) Bioavailability of interferon beta $1 \mathrm{~b}$ in MS patients with and without neutralizing antibodies. Neurology 52:1239-1243

26. Deisenhammer F, Mayringer I, Harvey J, Dilitz E, Gasse T, Stadlbauer D, Reindl M, Berger T (2000) A comparative study of the relative bioavailability of different interferon beta preparations. Neurology 54:2055-2060

27. Cook SD, Quinless JR, Jotkowitz A, Beaton P, Neutralizing Antibody Study Group (2001) Serum IFN neutralizing antibodies and neopterin levels in a cross-section of MS patients. Neurology 57:1080-1084

28. Vallittu AM, Halminen M, Peltoniemi J, Ilonen J, Julkunen I, Salmi A, Eralinna JP; Finnish Beta-Interferon Study Group (2002) Neutralizing antibodies reduce $\mathrm{MxA}$ protein induction in interferon-beta-1a-treated MS patients. Neurology 58:1786-1790

29. Bertolotto A, Gilli F, Sala A, Capobianco M, Malucchi S, Milano E, Melis F, Marnetto F, Lindberg RL, Bottero R, Di Sapio A, Giordana MT (2003) Persistent neutralizing antibodies abolish the interferon beta bioavailability in MS patients. Neurology 60:634-639

30. Gilli F, Bertolotto A, Sala A, Hoffmann F, Capobianco M, Malucchi S, Glass T, Kappos L, Lindberg RL, Leppert D (2004) Neutralizing antibodies against IFN-beta in multiple sclerosis: antagonization of IFN-beta mediated suppression of MMPs. Brain 127:259-268

31. Pachner AR, Dail D, Pak E, Narayan K (2005) The importance of measuring IFNbeta bioactivity: Monotoring in MS patients and the effect of anti-IFN beta antibodies. J Neuroimmunol 166:180188
32. Weinstock-Guttman B, Badgett D, Patrick K, Hartrich L, Santos R, Hall D, Baier M, Feichter J, Ramanathan M (2003) Genomic effects of IFN-beta in multiple sclerosis patients. J Immunol 171:2694-2702

33. Poser CM, Paty DW, Scheinberg L, McDonald WI, Davis FA, Ebers GC, Johnson KP, Sibley WA, Silberberg DH, Tourtellotte WW (1983) New diagnostic criteria for multiple sclerosis: guidelines for research protocols. Ann of Neurol 13:227-231

34. Bagnato F, Pozzilli C, Scagnolari C, Bellomi F, Pasqualetti P, Gasperini C, Millefiorini E, Galgani S, Spadaro M, Antonelli G (2002) A one year study on pharmaco-dynamic profile of interferon beta-1a in Multiple Sclerosis. Neurology 58:1409-1411

35. Kawade Y (1986) Quantitation of neutralization of interferon by antibody. Methods Enzymol 19:558-573

36. Antonelli G, Simeoni E, Bagnato F, Pozzilli C, Turriziani O, Tesoro R, Di Marco P, Gasperini C, Fieschi C, Dianzani F (1999) Further study on the specificity and incidence of neutralizing antibodies to interferon (IFN) in relapsing remitting multiple sclerosis patients treated with IFN beta-1a or IFN beta-1b. J Neurol Sci 168:131-136

37. Chieux V, Chehadeh W, Hautecoeur P, Harvey J, Wattre P, Hober D (2000) Increased levels of antiviral MxA protein in peripheral blood of patients with a chronic disease of unknown etiology. J Med Virol 65:301-308

38. Hijikata M, Ohta Y, Mishiro S (2000) Identification of a single nucleotide polymorphism in the MxA gene promoter $(\mathrm{G} / \mathrm{T}$ at $n t-88)$ correlated with the response of hepatitis $\mathrm{C}$ patients to interferon. Intervirology 43:124-127

39. Knapp S, Yee LJ, Frodsham AJ, Hennig BJ, Hellier S, Zhang L, Wright M, Chiaramonte $\mathrm{M}$, Graves $\mathrm{M}$, Thomas $\mathrm{HC}$, Hill AV, Thursz MR (2003) Polymorphisms in interferon-induced genes and the outcome of hepatitis $C$ virus infection: roles of $\mathrm{MxA}, \mathrm{OAS}-1$ and PKR. Genes Immun 4:411-419

40. Suzuki F, Arase Y, Suzuki Y, Tsubota A, Akuta N, Hosaka T, Someya T, Kobayashi M, Saitoh S, Ikeda K, Kobayashi M, Matsuda M, Satoh J, Kumada H (2004) Single nucleotide polymorphism of the MxA gene promoter influences the response to interferon monotherapy in patients with hepatitis $\mathrm{C}$ viral infection. J Viral Hepat 11:271-276

41. Bergkvist M, Olsson M, SandbergWollheim M (2004) No evidence for genetic linkage between development of multiple sclerosis and components of the IFN system and the JAK-STAT pathway. Mult Scler 10:87-88
42. Ross C, Svenson M, Hansen MB, Vejlsgaard GL, Bendtzen K (1995) High avidity IFN-neutralizing antibodies in pharmaceutically prepared human IgG. J Clin Invest 95:1974-1978

43. Grossberg SE, Kawade Y, Kohase M, Yokoyama H, Finter N (2001) The neutralization of interferons by antibody. I. Quantitative and theoretical analyses of the neutralization reaction in different bioassay systems. J Interferon Cytokine Res 21:729-742

44. Gneiss C, Reindl M, Berger T, Lutterotti A, Ehling R, Egg R, Deisenhammer F (2004) Epitope specificity of neutralizing antibodies against IFN-beta. J Interferon Cytokine Res 24:283-290

45. Gneiss C, Tripp P, Ehling R, Khalil M, Lutterotti A, Egg R, Mayringer I, Kunz B, Berger T, Reindl M, Deisenhammer F (2006) Interferon-beta antibodies have a higher affinity in patients with neutralizing antibodies compared to patients with non-neutralizing antibodies. J Neuroimmunol 174:174-179

46. Feng X, Petraglia AL, Chen M, Byskosh PV, Boos MD, Reder AT (2002) Low expression of interferon-stimulated genes in active multiple sclerosis is linked to subnormal phosphorylation of STAT1. J Neuroimmunol 129:205215

47. Lau AS, Hannigan GE, Freedman MH, Williams BR (1986) Regulation of interferon receptor expression in human blood lymphocytes in vitro and during interferon therapy. J Clin Invest; 77:1632-1638

48. Ambrus JL, Ambrus JL Jr, Chadha S, Novick D, Rubinstein M, Gopalakrishnan B, Bernstein Z, Priore RL, Chadha KC (1997) Mechanism(S) of interferon inhibitory activity in blood from patients with AIDS and patients with lupus erythematosus with vasculitis. Res Commun Mol Pathol Pharmacol 96:255-265

49. Mizukoshi E, Kaneko S, Kaji K, Terasaki S, Matsushita E, Muraguchi M, Ohmoto Y, Kobayashi K (1999) Serum levels of soluble interferon Alfa/ Beta receptor as an inhibitory factor of interferon in the patients with chronic hepatitis C. Hepatology 30:1325-1331

50. Chadha KC, Ambrus JL Jr, Dembinski W, Ambrus JL Sr (2004) Interferons and interferon inhibitory activity in disease and therapy. Exp Biol Med 229:285-290

51. Vlotides G, Sorensen AS, Kopp F, Zitzmann K, Cengic N, Brand S, Zachoval R, Auernhammer CJ (2004) SOCS1 and SOCS-3 inhibit IFN-alpha-induced expression of the antiviral proteins 2,5-OAS and MxA. Biochem Biophys Res Commun 320:1007-1014 